Ecology and Management of Cowbirds and Their Hosts 
THIS PAGE INTENTIONALLY LEFT BLANK 


\section{Ecology and Management}

of Cowbirds and Their Hosts

Studies in the Conservation of

North American Passerine Birds
EDITED BY

JAMES N. M. SMITH,

TERRY L. COOK,

STEPHEN I. ROTHSTEIN,

SCOTT K. ROBINSON,

AND SPENCER G. SEALY

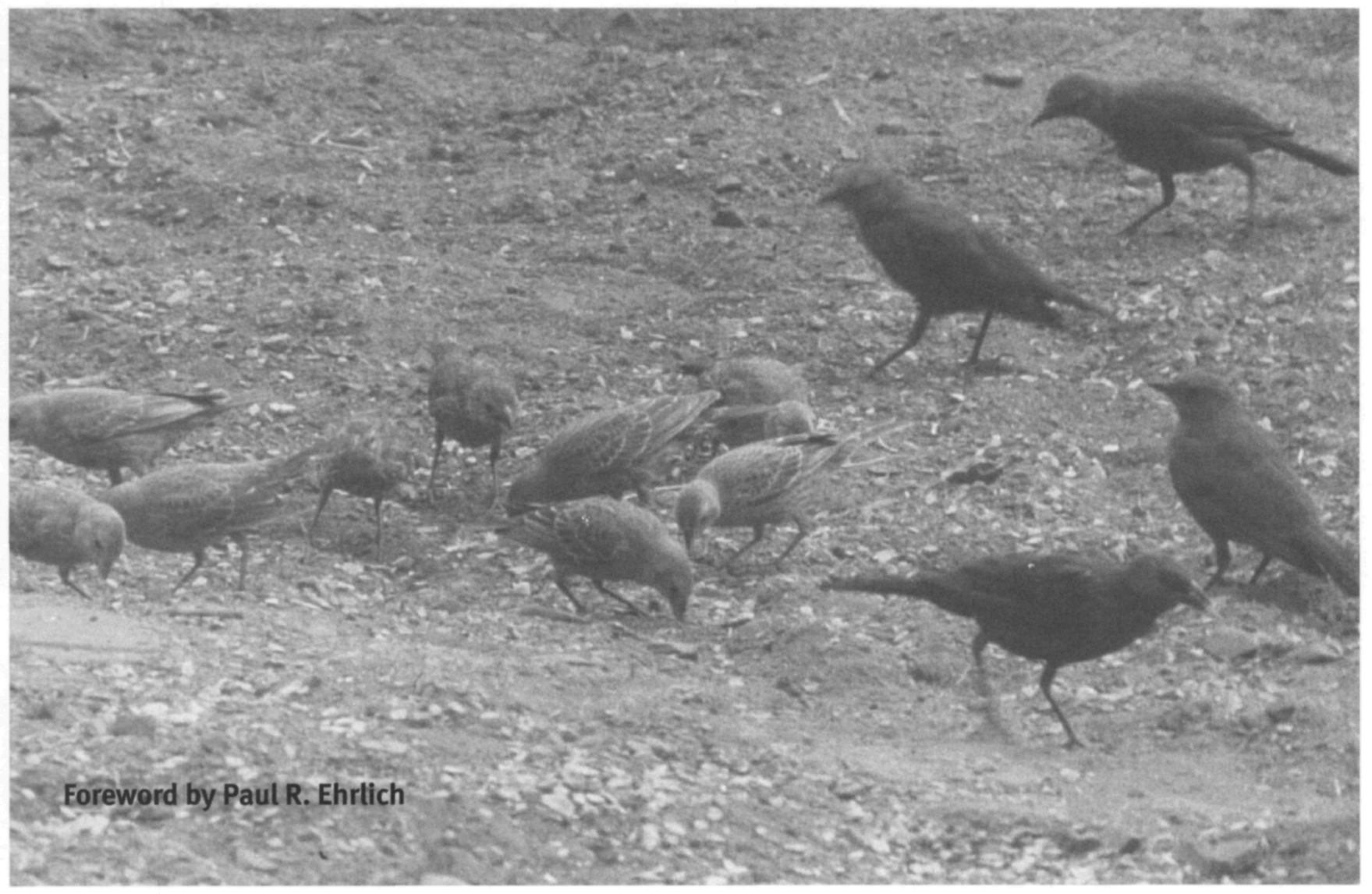

University of Texas Press

Austin

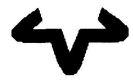


(c) Copyright $\odot 2000$ by James N. M. Smith, Terry L. Cook, Stephen I. Rothstein, Scott K. Robinson, and Spencer G. Sealy All rights reserved

Printed in the United States of America

First edition, 2000

Requests for permission to reproduce material from this work should be sent to Permissions, University of Texas Press, Box 7819, Austin, TX 78713-7819.

$\infty$ The paper used in this publication meets the minimum requirements of American National Standard for Information SciencesPermanence of Paper for Printed Library Materials, ANSI Z39.48-1984.

ISBN 0-292-77738-8

Library of Congress Cataloging-in-Publication Data

Ecology and management of cowbirds and their hosts : studies in the conservation of North American passerine birds / edited by James N. M. Smith ... [et al.] ; foreword by Paul R. Ehrlich. - 1st ed.

p. $\mathrm{cm}$.

Includes bibliographical references.

ISBN 0-292-77738-8 (hardcover : alk. paper)

1. Cowbirds. 2. Brood parasitism. 3. Wildlife management. I. Smith, James N. M., 1944-

QL696.P2475E26 2000

$598.8^{\prime} 74-\mathrm{dc} 21$

Title page photograph of a flock of juvenile Brown-headed Cowbirds by Stephen I. Rothstein. 